\title{
«Under krigen holdt vi sammen». Norske og svenske suicidrater 1940-45
} Av Arne Thorvilk

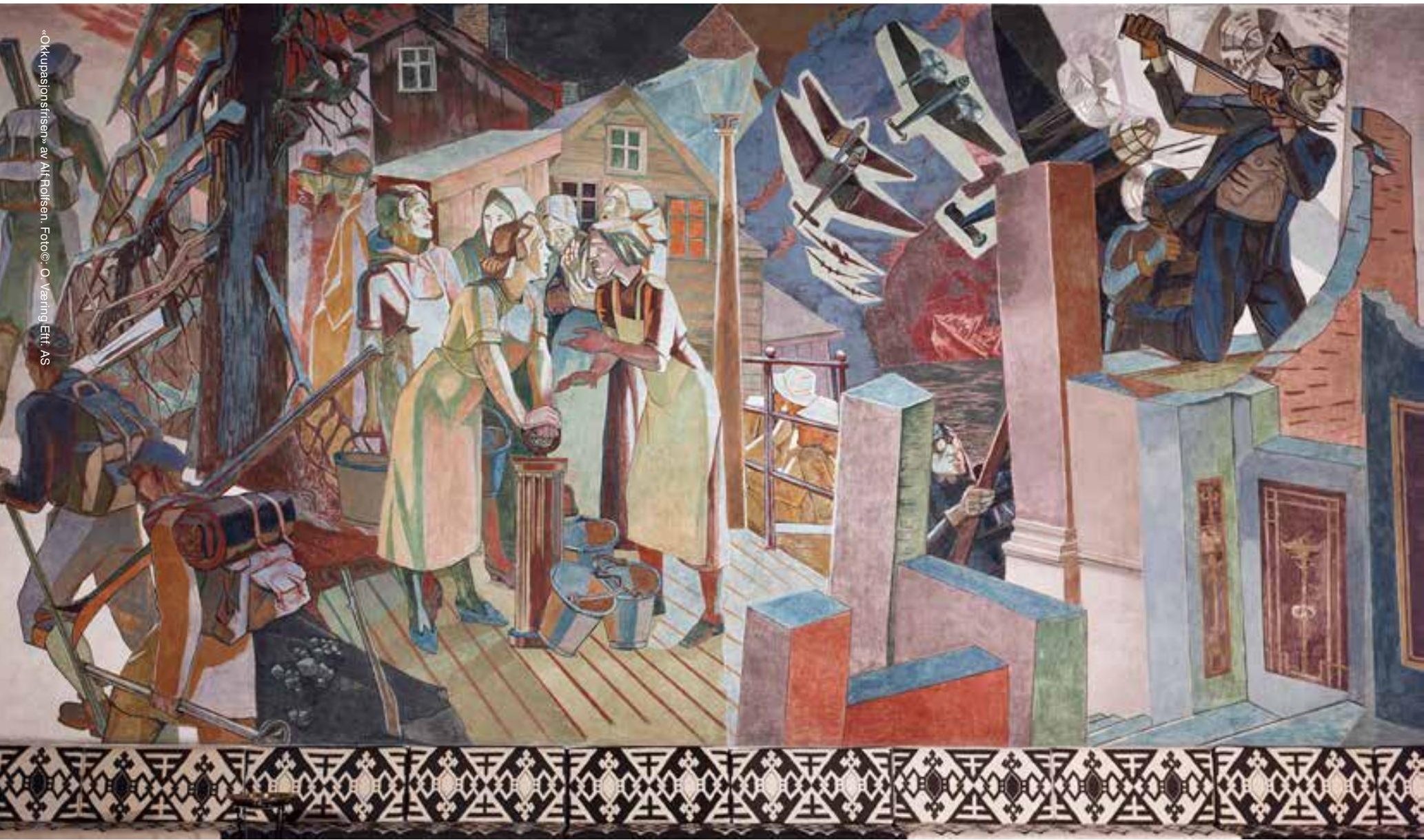

At selvmordsrater tenderer mot å falle i krigstider, er godt beskrevet i europeisk faglitteratur. Norge opplevde krig og okkupasjon i 1940-45, mens Sverige lyktes i å opprettholde nøytralitet. Hvordan utviklet norske og svenske selvmordsrater seg under annen verdenskrig, og hvorledes kan man i ettertid forstå endringene? Og hvordan var registreringsmåten? Ble de som søkte døden for ikke å røpe motstandsarbeid klassifisert som selvmordere? 
I Statistisk sentralbyrås rapport Sunnhetstilstanden og medisinalforholdene 1941 skriver byråsjef Julie Backer: «En vil legge merke til at selvmordshyppigheten var forholdsvis lavere i 1941 sammenliknet med tidligere år». Men hun legger til: «Det er imidlertid mulig at dette til en viss grad henger sammen med at opplysningene på dødsmeldingene ikke har vært så fullstendige som tidligere».

Dr philos Julie Elisabeth Backer (189o-1977) var en høyt utdannet kvinne, som hadde studert ved utenlandske universiteter. Etter all sannsynlighet har hun vært inneforstått med at fall i selvmordsrater i krigstid kan ha andre forklaringer enn ufullstendige dødsmeldinger. Kanskje var dette ikke en statistikers oppgave å tematisere, kanskje ville en slik tematisering vekke okkupasjonsmaktens mishag.

Noen år senere var Backer mer i stand til å konkludere. I Sunnhetstilstanden og medisinalforholdene 1946 heter det: «Selvmordshyppigheten var usedvanlig stor i 1940, men ellers under krigen var den lavere enn i normale tider. I 1945 fikk vi igien en voldsom økning i selvmordshyppigheten, men i 1946 lå den omtrent på samme nivå som før krigen». Og i hennes reviderte statistikk er "selvmord blant politiske fanger» ført som «politiske mord», relatert til «tyskernes og nazistenes overgrep mot den norske sivilbefolkning».

\section{Målsetting og metode}

Denne artikkelen har dobbelt målsetting: For det første å skissere teorier som historisk sett har vært anvendt for å forklare at suicidrater ofte reduseres i krigstid. Dernest er intensjonen å presentere norske og svenske suicidrater for årene 1940-1945, og tolke endringer i lys av beskrevet teoridannelse.

Innledningsvis gis en kortfattet presentasion av teori, der bidragene er hentet fra de franske sosiologene Émile Durkheim (1858-1917) og Maurice Halbwachs (1877-1945), samt den østerrikske legen Sigmund Freud (1856-1939).

Den empiriske delen av artikkelen bygger på statistisk materiale for krigsårene, tilgiengelig på nettsidene til Statistisk sentralbyrå i Norge (www.ssb.no) og Statistiska centralbyrån i Sverige (www.scb.se). Noe fag- og skjønnlitterært materiale som er kjent av forfatteren, er også lagt til grunn.

\section{Teori}

\section{Durkheims bidrag}

Under overskriften «Det egoistiske selvmordet» drøfter Durkheim hvordan krig og sosiale kriser virker inn på suicidrater. Etter Durkheims teori skjer «egoistiske selvmord» hos ensomme og utstøtte mennesker, de som er

\section{SAMMENDRAG}

Det er kjent at selvmordsrater tenderer mot å falle i krigstid, både i krigførende og i nøytrale land. Artikkelen gjennomgår historiske forklaringer på fenomenet, hentet fra sosiologiske klassikere (Durkheim og Halbwachs) og psykodynamisk teori (Freud). Førstnevnte fokuserer på økt integrasjon og samhold blant befolkningen når krig rammer, sistnevnte på at selvdestruktive da kan melde seg til fronttjeneste og andre farlige oppdrag.

Dernest presenteres norske og svenske suicidrater registrert under annen verdenskrig (1940-45). Norske rater viste sterkt fall $\mathrm{i}$ 1941, året da okkupasjonsmakten «strammet grepet», og et uvanlig høyt antall selvmord i 1945, året for frigjøringen. Svenske rater tenderer mot å reduseres de siste krigsårene.

Artikkelen drøfter hvordan man kan forstå de beskrevne endringene i selvmordsrater. At fall i norsk og svensk rate også forekommer i midlere og eldre aldersgrupper, og hos kvinner, styrker den sosiologiske hypotesen.

Videre tematiserer artikkelen at offerhandlinger tradisjonelt ikke har vært klassifisert som selvmord, noe som har relevans for Norge ved at etterkrigsrevisjonen av norske selvmordsrater ekskluderte nordmenn som hadde tatt sitt liv for ikke å røpe motstandsarbeid under forhør eller tortur.

\section{ABSTRACT}

It is well known that suicide rates tend to decline in times of war, both in countries engaged in warfare and in neutral countries. The article discusses how this phenomenon has been explained by sociological classics (Durkheim and Halbwachs) and within psychodynamic theory (Freud). The former claims that war strengthens integration and social ties within the population, while the latter postulates that self-destructive people may be more inclined than others to volunteer for war missions.

Furthermore, the article presents suicide rates of German-occupied Norway and neutral Sweden during the Second World War Norwegian rates dropped considerably in 1941 (the year in which the occupation of Norway brutalized), and then suddenly peaked in 1945, the year of liberation. Swedish rates tended, however, to become lower during the last years of war.

The article compares this statistical material with the mentioned models of explanation. The fact that Norwegian and Swedish suicide rates decreased not only in the young, but also within the middle aged and elderly population, and among women, seems to strengthen the sociological hypothesis.

Norwegian rates were revised after the war, and this revision excluded suicides among members of the resistance movement who killed themselves in order not to reveal information during interrogation or torture. Traditionally, a sacrifice like this has not been classified as suicide. 
for svakt integrert i fellesskapet. For denne gruppen kan krig ha en positiv, integrerende effekt: «Gjennomgripende sosiale forandringer og store kriger mellom nasjoner vekker kollektive følelser, stimulerer patriotisme og politiske og nasjonale følelser, og giennom at alle aktiviteter rettes mot ett og samme mål, oppstår en sterkere integrasjon i samfunnet, iallfall for en tid» (Durkheim 1897/1978: 95).

Her som ellers legger Durkheim sin samtids statistikker til grunn. Dansk suicidrate var påfallende lav i 1864, året for nederlaget mot Preussen og Đsterrike. Krigen i 187071 hadde samme virkning i franske byer og i noen (men ikke alle) krigførende tyske stater.

At den franske suicidraten ikke

I et større perspektiv kan Durkheims verk ses på som en kritikk av en tradisjonell medisinsk forståelse falt under Krimkrigen (1853-56), men tvert om nådde et høydepunkt i 1854, forklarer Durkheim med at dette var en perifer «krig mellom dynastier», som ikke engasjerte den jevne befolkning. - Tyske stater hadde i 1870-71 invadert store deler av Frankrike. Likevel kunne det for perioden 1870-72 bare påvises et fall i suicidrate i byer, mens statistikken faktisk viste okning i rurale strøk. Dette har ifølge Durkheim sammenheng med at bybefolkningen er mer sensitiv («plus sensible»), og det bare er i byer at krig fører til det moralsk engasjement («action morale») (Durkheim 1897/2013: 220-221).

Durkheims forklaringsmodell er derfor sårbar for samme kritikk som har vært anvendt overfor Freuds teorier: Den er i liten grad falsifiserbar. Dersom krigstilstand ikke fører til fall i suicidrate, er det ifølge Durkheim relatert til at aktuelle krig ikke har mobilisert de patriotiske følelsene og den sosiale integrasjonen som er nødvendig for at så skal skje. Generelt har kritikere pekt på at hans verk Selvmordet (Le Suicide) ikke bare er basert på empiri, men i stor grad på Durkheims forforståelse (Douglas 1967)

\section{Halbwachs' bidrag}

Durkheim hadde hevdet at fall i selvmordsrate hos krigførende nasjoner ikke kan forklares med mangelfull statistikk. Denne påstanden har vært bestridt, også i nyere tid (Hammerlin \& Enerstvedt 1988). Krig vil kunne vanskeliggiøre myndighetens registrering av suicid, og sannsynligvis vil slik registrering ikke være noen prioritert oppgave i en krigssituasjon.

På dette punktet er den franske sosiologens Maurice Halbwachs' studier av interesse. Halbwachs videreforte Durkheims arbeid innen suicidologi, men tok også for seg hvordan suicidrater i krigstid endres i nøytrale stater. Foruten Sveits' studerte han ratene for Norge, Sverige og Danmark under første verdenskrig (1914-18), og bemerket at samtlige viste et fall.

Halbwachs supplerer Durkheim ved å påpeke at krig endrer samfunnsstruktur i nøytrale land. Det sosiale livet blir mindre vitalt, det er færre arenaer for utfoldelse og dermed også for destruktive interpersonlige konflikter. Ifølge Halbwachs oker denne dynamikken mot slutten av en storkrig, og forklarer at ratene i Norge og Sverige nådde et bunnivå rundt 1918, og for danske byer i 1919 (Halbwachs 1930/2002: 246-47).
Halbwachs' hypotese kan ha generell relevans. Derimot synes den ufullstendig som forklaring på fall i nordiske rater under første verdenskrig. Rett nok greide Skandinavia å opprettholde formell nøytralitet. Som tysk naboland var Danmark likevel truet, Sverige var involvert militært i Østersiøen, og stormaktene hadde åpenbar interesse av norsk territorialfarvann og kystlinje. Norge måtte innføre rasjonering for levnetsmidler, og lå på verdenstoppen når det gjaldt senket handelstonnasje, med et tilsvarende tap av menneskeliv. Kanskje ble samfunnslivet forenklet slik Halbwachs postulerer, men krigen i Europa har etter all sannsynlighet medført kollektive følelser og sosial integrasion også i de skandinaviske landene, samsvarende med Durkheims forklaring.

\section{Freuds bidrag}

I et større perspektiv kan Durkheims verk ses på som en kritikk av en tradisjonell medisinsk forståelse. Samtidens psykiatri hadde overveiende sett suicid som følge av medisinske tilstander. Durkheim argumenterer med at det i så fall er vanskelig å forklare hvorfor fenomenet varierer med demografiske variabler og politiske forhold, som krig, men ikke i samsvar med datidens registrering av alvorlige psykiske lidelser.

Et mer utfyllende medisinsk bidrag ble gitt av Freud i det tidlige verket Dagliglivets psykopatologi (Zur Psychopathologie des Alltagslebens). Freud hevder her at psyken også inneholder selvdestruktive impulser, som vil kunne medføre tendens til å oppsøke risikosituasioner. Tilsynelatende heltemot i krig kan være relatert til et ubevisst dødsønske. Kasuistisk beskrives en livstrett offiser som melder seg frivillig til en kolonikrig som tidligere ikke har fanget hans interesse. Freud bemerker at slagmarken er stedet der selvmord kan skje, men likevel skjules (Freud 1904)

Kanskie kan dette forklare krigstiders nedgang i suicidrate for menn i yngre aldersgrupper, men i liten grad for ovrige deler av befolkningen. Imidlertid kom Freud i senere verk til å se krig som en kollektiv prosess, der primitiv aggresion dominerer store befolkningsgrupper. Nettopp denne aggresionen, rettet mot en ekstern fiende, virker vitaliserende på enkeltindividet, og motvirker den innadrettede destruktiviteten som psykoanalytisk tradisjon etter hvert kom til å se på som «suicidets nøkkel» (Freud 1991/Thorvik 2008).

Det bør presiseres at Freud neppe hadde som målset-

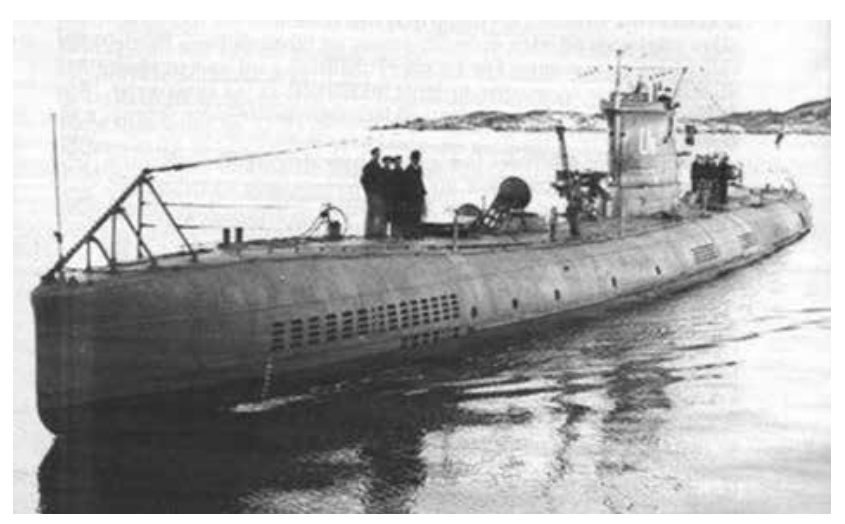

Den svenske ubåten Ulven, som gikk på en tysk mine i april 1943. Hele mannskapet omkom. 
ning å gi en fullstendig forklaring på at selvmordsrater tenderer mot å falle i krig, og ikke drøfter statistisk materiale.

\section{En motsetning?}

Man kan diskutere i hvilken grad Durkheims og Freuds teorier er forenlige. Generelt hevder Durkheim at suicid reguleres av menneskets relasjon til samfunnet. Freud tar på sin side utgangspunkt i individets intrapsykiske prosesser, herunder aggresjon og selvdestruktivitet. For begge teoretikere gielder at krig er et ekstremfenomen, som tydeliggiør de mekanismene som gielder i fredstid.

Umiddelbart synes det å være en forskjell at Durkheim vektlegger samfunnet som en potensielt skapende instans, mens Freuds dynamikk er tilgrunnliggende destruktiv. Men det bør nevnes at Freud også postulerer at underbevisstheten inneholder «erotiske og idealistiske» impulser, og at kollektivet får betydning i krigssituasjoner (Freud 1991: 357). For en generell sammenlikning av Durkheim og

\section{Durkheim} vektlegger samfunnet

som en poten-
sielt skapen-
de instans,
mens Freuds
dynamikk er til-
grunnliggende
destruktiv

Freuds teoridannelser vises det til den norske sosiologen Dag Dsterbergs innledning til den norske utgaven av Selvmordet.

\section{Empiri \\ Norske suicidrater}

Nedenfor presenteres et sammendrag av norske suicidrater for årene 1940-45, slik de fremkommer i Statistisk sentralbyrås årlige rapporter for perioden (kalt Folkemengdens bevegelse og Sunnhetstilstanden og medisinalforholdene).

Rater for årene 1940 og 1941 ble vel å merke ferdigstilt første gang i henholdsvis 1941 og 1944. Reviderte rater ble så presentert i 1949. Det heter i forordet til Folkemengdens bevegelse 1942-45: «Etter frigjøringen fikk en ved henvendelse til den militære overkommando opplysning om dødsfall blant norske militære ute og hjemme. Melding om sjøfolk og andre sivile døde i utlandet mottok Byrået giennom henholdsvis Handels og Utenriksdepartementet. Oppgave over politiske fanger som var døde i utlandet, er vesentlig hentet fra Sosialdepartementets fangekartotek». Det fremgår også at rater er basert på «den norske befolkning», det vil si at tyske og andre utenlandske statsborgere er ekskludert.

I tekst nedenfor er både opprinnelig og revidert rate angitt. Kursivert parentes refererer til tall for henholdsvis menn og kvinner. Alle data er hentet fra nevnte kilder, men rate er konsekvent ført som antall suicid pr 100 ०००, og begrenset til en desimal.

I motsetning til den svenske oppgir norsk statistikk ikke spesifikk rate for definerte aldersgrupper, men bare endringer i antall (numerisk endring).

\section{0}

Statistisk sentralbyrås rapporter viser en rimelig stabilitet i suicidrate den siste delen av 1930-årene. I 1938 var raten 7,0 $(10,8+3,4)$, mens den i 1939 var den $6,8(11,2+2,5)$. Raten for 1940 var først anslått til 6,9 $(11,5+2,5)$, senere revidert til 7,1 $(11,9+2,5)$.
1941

Ifølge den opprinnelige Sunnhetstilstanden og medisinalforholdene for 1941 er suicidraten dette året falt til 4,3; mens etterkrigsrevisjonen angir $4,4(7,2+1,7)$. Samlet reduksjon er nær $40 \%$.

Statistisk materiale viser (numerisk) reduksjon for nesten alle aldersgrupper, sammenliknet med 1940. Unntaket er gruppen 20-24 år, der det faktisk er en lett økning. Dvrige aldersgrupper viser nedgang, men denne er mest uttalt for gruppen 40-49 år, dernest for 50-59 år. Også for de eldste aldergruppene er det til dels betydelig fall.

Når det gielder dødsmåten, viser statistikken størst nedgang for hengning (- $34 \%$ ). Reduksjonen i antall suicid er mest uttalt i byene (- $52 \%$ ), noe mindre i datidens landdistrikter (- $32 \%)$

\section{$1942-1944$}

I disse krigsårene skjer en økning, men samlet rate når ikke opp til nivået i 1939-40. I 1942 er raten 5,0 (7,9 + 2,2), i 1943 er den $5,3(8,7+2,9)$ mens den i 1944 er $5,6(8,3+3,1)$. Den største okning synes å være i aldersgruppen 30-39 år, for øvrig varierer tallene uten noe klart mønster.

\section{5}

For fredsåret angir Sunnhetstilstanden og medisinalforholdene 1945 med sammenlikningstabeller en dramatisk stigning. Samlet rate er 9,3 $(14,9+3,9)$, det vil si $66 \%$ mer enn i 1944 .

Økning er til stede i alle aldersgrupper, men er (numerisk) mest fremtredende i de midterste (30-39, 40-49 og 50-59 år). Unntaket er gruppen 20-24 år, der det faktisk er en lett reduksion. Geografisk er okningen markant større i byene $(+112 \%)$ enn i landdistriktene $(+48 \%)$. I Oslo er det i 1945 registrert 50 suicid $(33+17)$, mot 16 (11 +5) i 1944 .

Fenomenet er begrenset til 1945. Fra 1946 er raten omtrent på samme nivå som før krigen.

\section{Svenske suicidrater}

Tilsvarende gis det nedenfor et sammendrag av svenske suicidrater for årene $1940-45$, slik de presenteres i Statistiska Centralbyråns årlige rapporter for perioden (kalt Folkmängden och dess förändringar og Dödsorsaker). Disse er jevnt over publisert tre år etter aktuelle år. For det nøytrale Sverige har en revisjon etter 1945 ikke vært påkrevet.

Svensk statistikk viser en lett stigende tendens i siste halvdel av 1930-årene. Det er verd å merke seg at svenske (og danske) rater på denne tiden lå vesentlig høyere enn de norske [en forskjell som vedvarte langt inn i etterkrigstiden, og som er gitt navnet «The Scandinavian Suicide Phenomenon» (Thorvik 2007)].

I 1938 er raten $15,8(25,0+6,8)$, i 1939 er $16,2(25,5+7,0)$ mens den i 1940 er $17,1(27,2+7,1)$. Sistnevnte kommenteres som som «än obetydelig stegring för vartdera könet $\mathrm{i}$ ¡ämförelse med år 1939», og er jevnt fordelt mellom aldersgrupper (Dödsorsaker 1940: 11).

I de kommende krigsårene viser svenske rater en fluktuerende, men nedadgående tendens for menn. I 1941 er raten $15,8(24,7+7,0)$, i 1942 synker den videre til 14,3 (21,8 $+7,0)$, mens den i 1943 øker til 15,1 $(22,3+8,1)$.

Fra 1943 til 1944 inntreffer så en betydelig reduksion («avsevärd minskning») for begge kjønn. Registrert rate 


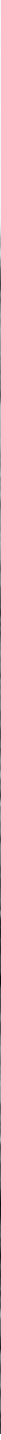

for 1944 er 13,1 $(20,6+5,7)$, det vil si et fall på over $13 \%$. De fleste aldersgrupper viser redusert rate, men denne er mest uttalt for de mellom 30-40 år. (Dödsorsaker 1944: 11). Mens det i januar 1943 var registrert 98 suicid, er tallet for januar 1944 gått ned til 50, som er det laveste antall registrert i en kalendermåned i Sverige under den annen verdenskrig.

Størst numerisk nedgang i dødsmåte viser «Hängning och strypning», som i 1943 utgiorde 371 (38\%) av alle suicid. I 1944 er tallet 300.

I 1945 registreres en okning, om enn ikke så stor som i Norge. Dette året er raten $15,3(23,1+7,7)$, det vil si nær $17 \%$ mer enn i 1944. I kommentar fra Statistiska Centralbyrån heter det at 34 av de angieldende er utenlandske statsborgere.

Også for Sverige er raten i de første etterkrigsårene omtrent på samme nivå som før krigen.

\section{Diskusjon}

\section{Selvmordsratenes validitet}

Hvorvidt offisiell statistikk er gyldig (valid) og gienspeiler det faktiske antall selvmord, er en kjent problemstilling innen suicidologi. Det er nevnt at norske rater ble revidert
Hvorvidt offisiell statistikk er gyldig og gjenspeiler det faktiske antall selvmord, er en kjent problemstilling innen suicidologi

i de første etterkrigsårene, og at kritikere har pekt på at krig kan implisere at statistikk blir mindre nøyaktig.

Interessant nok er denne problematikken også relatert til hvordan selvmord defineres. Etterkrigsrevisjonen for årene 1942-45 fører 46 «selvmord hos politiske fanger» i samme rubrikk som «politiske mord», og disse inkluderes derfor ikke i suicidraten. De angieldende hadde kastet seg ut av vinduer mens de ble forhørt av Gestapo, eller suiciderte på annen måte mens de ble holdt fanget. Det er neppe tvil om at de hadde suicidal intension. Men dette var mennesker som i utgangspunktet ville livet, men som ufrivillig var satt i en ekstremsituasjon. For mange hadde selvmordet karakter av et offer: Man døde fremfor å røpe sine kamerater under forhør eller tortur. Medlemmer av etterretningsorganisasjonen XU fikk av den grunn utdelt giftkapsel til å bruke hvis de ble avslørt (Sæter \& Sæter 2007). Å ofre seg for fel- 


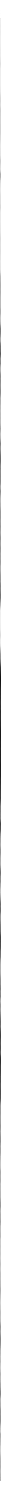

lesskapet har siden antikken vært ansett som en handling som er kvalitativt annerledes enn ordinært suicid. Også Halbwachs så det nødvendig å supplere Durkheims definisjon av selvmord ved å ekskludere denne typen offerhandlinger («sacrifice») (Halbwachs 1930/2002: 339).

Videre vil validitet i krigstider kunne svekkes ved en annen mekanisme: At politiske drap blir kamuflert som suicid. Det kan ikke utelukkes at dette har skjedd i Norge. De senere årene har dødsfallet til motstandsmannen Kai Holst (1913-45) vært diskutert i media. Offisielt suiciderte Holst kort tid etter fredsslutningen, mens flere i kretsen rundt ham har hevdet at han ble myrdet. Tilsvarende kasuistikker er beskrevet i andre land . Eksempelvis har pårørende til et fremtredende medlem av Nederlands nasjonalsosialistiske parti ment at vedkommende ikke suiciderte etter frigiøringen i 1945, men døde som følge av mishandling (Ultee et al 2009).

Et annet og mer omfattende spørsmål er om den ovrige norske statistikken er valid. Mens dødsårsaker i årene 1927-40 var blitt kodet etter interskandinavisk liste av 1926, gikk Statistisk sentralbyrå i 1941 over til å giøre bruk av den femte revisionen av den internasionale dødsårsaksklassifikasjonen (ICD-5) (Gjertsen 2002). Nettopp det var bakgrunnen for byråsjef Backers bemerkning i statistisk årbok for 1941 om at fall i suicidrate dette året kunne ha sammenheng med endrede dødsmeldinger.

Imidlertid kom Backer i senere publikasjoner til å tendere mot at denne endringen var uten særlig betydning. I et oversiktsarbeid fra 1961 bemerker hun at det nye klassifikasjonssystemet medførte forandring i sykdommers rekkefølge. «Men ellers var det praktisk talt full overensstemmelse mellom de enkelte numre i de to lister, slik at de forskjellige diagnoser i dødsårsaksstatistikken for perioden 1927-1940 og 1941-1950 forholdsvis lett lar seg sammenligne». Hun viser også til at klassifikasjonsreglene var de samme for begge perioder (Statistisk sentralbyrå 1961: 39).

I så fall kan man hevde at beskrevet fall i norsk suicidrate i årene 1941-44 i det minste speiler en valid tendens. Et vektig argument er også at svenske rater for perioden viser en reduksion. I motsetning til Norge beholdt Sverige den opprinnelige interskandinaviske klassifikasjonen helt frem til 1951, det vil si at klassifikasionsmåten var uendret under den annen verdenskrig (Smedby \& Schidler 2006). Det er ingen umiddelbar grunn til at klassifikasjon i det nøytrale Sverige skulle være mindre nøyaktig for årene 
1940-45. Svensk statistikk fremstår også som mer detaljert enn den norske, blant annet ved at Statistiska Centralbyrån oppgir antall suicid per måned, og spesifiserte rater for aldersgrupper.

For begge land gielder at hengning og strangulering utgiør den største nedgangen, altså en metode der det i alminnelighet ikke er tvil om suicidal intensjon.

\section{Hvordan forstå endringene i selvmordsratene?}

Hvordan kan så endringen i suicidrater forstås eller tolkes, gitt at endringene er valide?

\section{Norge}

For Norges del foreligger det ikke samvariasjon mellom det tyske angrepet den 9. april, det kortvarige norske felttoget og suicidrater for året 1940. Disse viser en lett stigning sammenliknet med foregående år. En forklaring kan være at situasjonen var mer preget av forvirring og fragmentering enn enhetlig nasional motstand.

Derimot reduseres suicidraten med nærmere $40 \%$ fra 1940 til 1941. Reduksjonen vedvarer frem til 1945, dog med en okning i 1942-44.
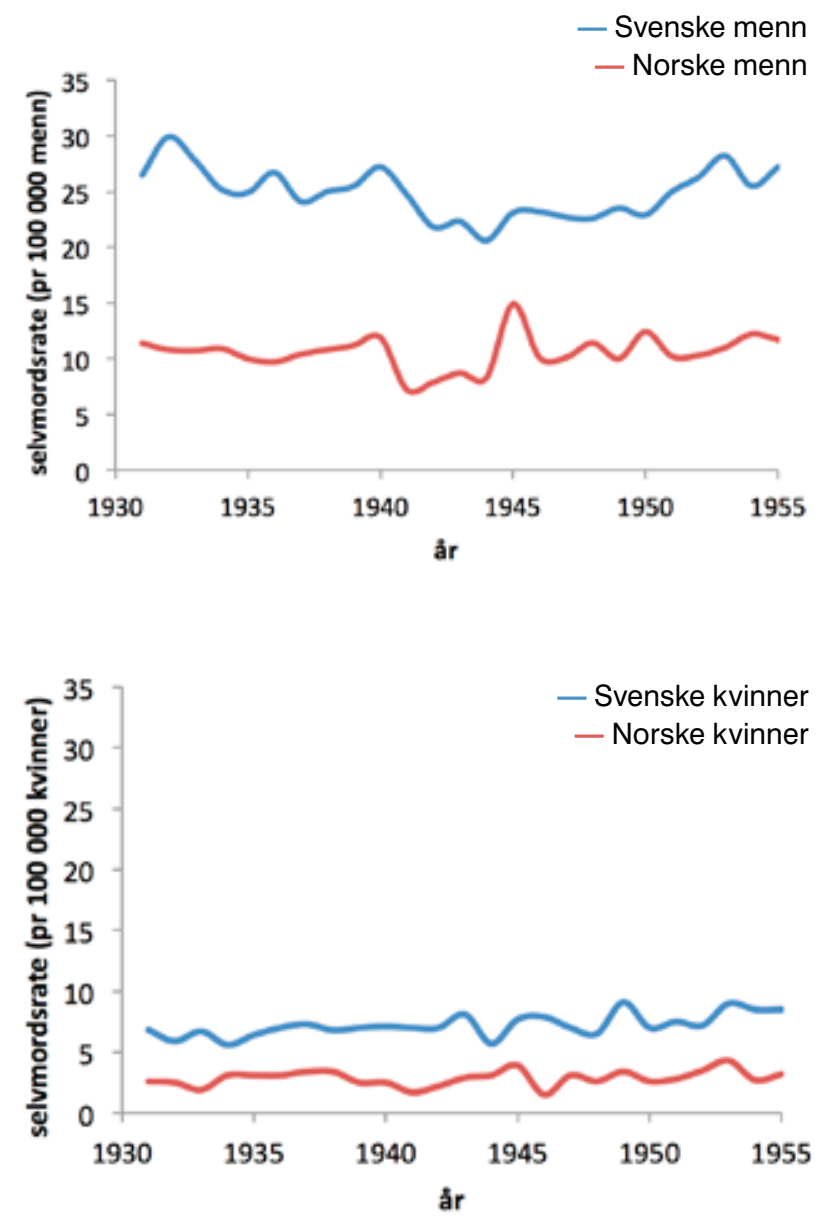

Kilder: Statistisk sentralbyrå og Statistiska Centralbyrån
I 1941 startet organiseringen av frivillige til tysk fronttieneste. Parallelt ble norske militæravdelinger opprettet i Storbritannia. Med bakgrunn i Freuds teoridannelse vil man kunne hevde at nedgang i rate var relatert til at selvdestruktive (men stridsdyktige) unge menn hadde mulighet til å melde seg til aktive krigshandlinger [eller delta i hjemmefrontens aksioner, som i all hovedsak ble utført av menn i 20-årene (Ivar Kraglund, Norsk Hjemmefrontmuseum: personlig meddelelse)]. På gruppenivå understøttes imidlertid ikke dette av statistikken, som viser reduksjon for begge kiønn, og mest i de midlere og eldre aldersgruppene.

I lys av Durkheims teori om kollektive emosjoner og øket integrering er det relevant å nevne at 1941 var året da tyskerne «strammet grepet». Høyesterett hadde nedlagt sine embeter i desember året før, i februar offentliggiorde kirkeledere en protest angående brutaliseringen av samfunnet, og også fagbevegelsen uttrykte økende misnøye. «Melkestreiken» i Oslo, som i utgangspunktet hadde et trivielt mål, resulterte at to fagforeningsledere ble henrettet i september. Nettopp dette er beskrevet som et vendepunkt.

I romanen Englandsfarere forsøker hovedpersonen å distansere seg fra den tyske okkupasjonen, inntil en nyhetsmelding giør ham til aktiv motstandsmann: «Stemmen som sa at Hansteen og Wickstrøm var skutt» (Evensmo 1947).

En voluminøs etterkrigslitteratur har tematisert hvordan de videre krigsårene kom til å bli preget av samhold. Okkupasjonsmakten og de nazifiserte myndighetene hadde liten støtte i det brede lag av folket. Rasjonering og knapphet på varer ga støtet til matauk og fellesskap.

At suicidraten de siste krigsårene har noe stigning, samsvarer med Durkheims påstand om at effekten av kollektive følelser (øket integrasjon, samhold og patriotisme) kan være midlertidig, og at suicidraten av den grunn tenderer mot å øke i «seirende» land mot slutten av kriger. Kasuistisk er det også beskrevet suicid blant NS-medlemmer etter at det ble tydelig at Tyskland kom til å tape krigen (Hoel 1947: 51)

\section{Suicid blant jøder etter oktober 1942}

Selv om verken norsk eller svensk selvmordsstatistikk opplyser om etnisk tilhørighet, bør jødenes skjebne gis særskilt omtale. Den jødiske befolkning i Norge ved krigens utbrudd er anslått til 2100-2200 personer. Det er kjent at minst 10 norske jøder suiciderte i årene 1942-44, hvorav halvparten i månedene etter at deportasjonene til Tyskland startet i oktober 1942. Tilsvarende er beskrevet hos nederlandske jøder, men i da langt større format (Ultee et al 2009). Med ett unntak er de angjeldende norske jødene født før forrige århundreskifte, altså middelaldrende og eldre personer. På samme måte som i Nederland er det også i Norge en overvekt av suicid blant jøder som i årene før krigen hadde flyktet fra Tyskland, og som på den måten kjente til nazismens brutalitet (Mats Tangestuen, Iødisk museum: personlig meddelelse). At fenomenet tross alt hadde mindre omfang i Norge, kan være relatert til at norske jøder hadde en fluktmulighet som de nederlandske manglet: et nøytralt naboland.

Teoretisk kan dette ses i lys av Durkheims litt glemte term fatalistiske selvmord. I en fotnote i Selvmordet vises det til at suicid kan være relatert til mangel på mulighet 
for livsutfoldelse, som hos slaver (Durkheim 1897/1978: 162). Som ettertiden har vist, var en forutanelse om manglende livsmulighet høyst realistisk for norske jøder under annen verdenskrig.

\section{Selvmordsraten i 1945}

Suicid blant NS-medlemmer er å regne som den «offisielle» forklaringen på at suicidraten økte drastisk i 1945 . Aftenposten skriver 5. januar 1946 at den altoverveiende delen av selvmord det foregående året fant sted etter kapitulasionen i mai, og at dette illustrerer «den fortvilelse som da rådde i visse kretser». Fenomenet ble også omtalt i medisinsk faglitteratur (Langfeldt 1951: 401). Kasuistisk er det beskrevet at hele NS-familier suiciderte, og tok mindreårige med seg i døden (Ulateig 2015).

Disse selvmordene kan også forstås ideologisk. Durkheim hadde tematisert at selvmord i en gitt kontekst kan
Suicid blant

NS-medlemmer er å regne som den «offisielle» forklaringen på at suicidraten økte drastisk i 1945 endre status fra å være uønsket til å bli godtatt, endog verdsatt. Før 1945 hadde nazismen vurdert suicid som et uttrykk for svakhet og dekadanse. Kuriøst kan det nevnes at en nordmann som i okkupasjonens første fase hadde uttalt på Oslo-trikken at "tyske offiserer skal ha skutt seg» ble stevnet grunnet ringeakt, og saken førtes helt til den kommissariske Høyesterett (Graver 2015: 80). Mot slutten av krigen skjedde en ideologisk endring. Sentrale tyske ledere, som propagandaminister Goebbels, roste antikkens hærførere som hadde dødd for egen hånd fremfor å søke nåde hos fienden (Goeschel 2009: 154). Det samme var tydelig i Norge. I landssviksaken mot en sentral NS-lege inngikk at han i krigens siste fase hadde produsert «selvmordspiller» til bruk for partimedlemmer (Espen Søbye: personlig meddelelse).

Det kan også nevnes at studier som ble utført umiddelbart etter krigen mente å påvise øket psykopatologi og psykisk sårbarhet hos NS-medlemmer og andre som ble omtalt som landssvikere, men det vitenskapelige grunnlaget for disse konklusjonene er senere sterkt bestridt (Lavik 1994).

Likevel finnes det også andre forklaringer på den høye raten i 1945. Distein Strømnæs (1914-80) var leder for etterretningsorganisasjonen XU. Ifølge XU - i hemmeleg tieneste 1940-45 formidlet han i 1974 til en norsk historiker at han kjente til at en rekke XU-agenter og andre motstandsfolk hadde suicidert våren og forsommeren 1945 . Han omtalte da dette som en «selvmordsepidemi», som han så som reaksion på det umenneskelige presset disse menneskene hadde opplevd under okkupasjonen (Sæter 2007: 228)

Kasuistisk er det også beskrevet at overlevende norske jøder suiciderte etter å ha fått visshet om den skjebnen som hadde rammet deres familier (Sidsel Levin, Iødisk museum: personlig meddelelse).

\section{Sverige}

Også svenske rater viser en lett stigning i 1940, sammenliknet med foregående år. At 12 ooo svenske frivil- lige meldte seg til den finske vinterkrigen november 1939 - mars 1940, er altså ikke assosiert med noen endring. (Boëthius 1991).

I årene 1941-44 viser svenske rater en klar nedadgående tendens, selv om det i 1943 er noe økning. Den mest påfallende endringen inntreffer fra 1943 til 1944, ved at raten faller betydelig for begge kjønn. Som beskrevet er reduksjonen også i Sverige mest uttalt for midlere aldersgrupper.

Årene 1939-45 har for Sveriges del vært kalt beredskapstiden. Landet unngikk å bli dratt inn i storkrigen, men det svenske samfunnet var likevel sterkt berørt. Nærmere 1900 svenske statsborgere omkom i krigsforlis, som soldater eller i krigsrelaterte ulykker (Statistiska Centralbyrån 1955: 49). En tyskvennlig «balansegang» $\mathrm{i}$ de første krigsårene endret seg i 1943, da myndighetene orienterte seg mot vestmaktene. At den svenske regiering denne sommeren avsluttet avtalen om «permittenttraffiken» (tyske troppetransporter over svensk territorium til Norge og Finland), skapte øket spenning (Hadenius 1974).

I lys av dette kan fallet i suicidrater, og da spesielt fra 1943 til 1944, forklares med krigsfrykt, kollektive emosioner og sosial inkludering i det svenske samfunn. Dette er samsvarende med Durkheims teoridannelse. Derimot er det ikke åpenbart at beredskapstiden ga mindre potensial for medmenneskelige konflikter, slik Halbwachs hadde forklart fall i suicidrater i stater som forholdt seg nøytrale. Både politisk overvåkning og begrenset pressesensur fant sted, og er beskrevet som konfliktskapende (Boëthius 1991, Moberg 1969). Det er likevel korrekt at reduksjonen ble mest fremtredende mot slutten av krigen, samsvarende med hva Halbwachs generelt postulerte for nøytrale land.

\section{Selvmordsraten i 1945}

At svenske rater i 1945 stiger til nærmere førkrigsnivået, kan ses i lys at det fra årets begynnelse var tydelig at krigen gikk mot en snarlig avslutning. Når Statistiska Centralbyrån nettopp for dette året presiserer hvor mange utenlandske statsborgere som inngår i det statistiske materialet er det muligens en hentydning til politisk relaterte suicid. Det bør nevnes at selvmord og selvmordsforsøk er et sentralt tema i P.O. Enquists dokumentarroman om Sveriges utlevering av baltiske soldater til Sovjetunionen etter krigens slutt (Enquist 1968).

\section{Avslutning}

Denne artikkelen har tatt utgangspunkt i tilgjengelig statistisk materiale. Bak hvert siffer skjules en personlig smerte.

Mulige statistiske normalvariasjoner er ikke drøftet i denne artikkelen. Statistiker ved Universitetet i Oslo har analysert norske rater for perioden 1931-55, uten å kunne påvise signifikante trender (Quirino Puzo, Nasionalt senter for selvmordsforskning og - forebygging: Personlig meddelelse).

Samlet sett kan det se ut til at det var reelt fall i suicidrater i Norge under annen verdenskrig, slik byråsjef Backer beskrev. Dette gielder begge kiønn, og er mest fremtredende for midlere aldersgrupper. Enn videre er reduksjonen størst i byer (slik Durkheim hadde hevdet), men lar seg også påvise i landdistrikter. 
Også svenske rater viser reduksion, om enn senere og i noe mindre format.

Med hensyn til forforståelse er denne artikkelen begrenset til Durkheims, Halbwachs' og Freuds teoridannelser. Forklaringsmodeller som endring i arbeidsmarked, generell sykelighet eller øket fokus på primærbehov er ikke diskutert.

Et moment bør nevnes: I krigsårene ble råvarer som brukes til fremstilling av alkohol prioritert til matproduksion. Rasjonering av vin og brennevin, og begrenset tilgiengelighet av øl, førte til at årlig alkoholkonsum per innbygger falt med cirka en liter i perioden 1940-1945 (NOU 1995: 24).

Studier av andre historiske perioder med minsket alkoholtilgang har vist assosiert fall av selvmordsrate. At nedgangen overveiende er påvist hos alkoholmisbrukere, gir støtte til at alkohol opptrer som en selvstendig faktor, og at minsket konsum bidro til reduksjon i suicid i Norge under annen verdenskrig (Nordström 2013).

Alders- og kjønnsfordelingen gir ikke belegg for at nedgangen var relatert til at mennesker med selvdestruktivitet søkte seg til fronttieneste eller risikooppdrag. Det statistiske materialet støtter på den måten ikke Freuds teori, derimot Durkheims vektlegging av øket sosial integrasjon. Fra dagligtale er det kjent at «nordmenn holdt sammen under krigen».

Dette er vel å merke en betraktning på gruppenivå.. At aktiv krigsdeltakelse kunne være relatert til personlig mistilpasning og psykopatologi, var et kjent tema i etterkrigstidens skiønnlitteratur.

Som tematisert innledningsvis, kan man diskutere i hvilken grad det er noen vesentlig motsetning mellom teoriene som Durkheim og Freud presenterer. I sitt senere forfatterskap trakk Freud nettopp frem kollektivets betydning. Det er også verd å merke seg hans poeng om at krigstid kan ha til følge at livet engasjerer på en annen måte enn før. Allerede i to år etter krigens slutt kunne en norsk forfatter se nesten nostalgisk tilbake på okkupasionstiden: «Den var så annerledes» (Hoel 1947: 56).

Krig er en ekstremsituasion med tilsvarende ekstreme psykologiske prosesser. Frontsoldater kan «innstille seg på å dø» uten at de er suicidale i ordinær forstand, mens de som er i sikkerhet vil kunne oppleve dette som et svik overfor kamerater. Et eksempel nevnes: Forfatteren Nordahl Grieg (1902-43) skal på slutten av sitt liv ha uttalt at han hadde svindlet dersom han slapp levende fra krigen. At han frivillig søkte seg fra skrivebordsarbeid til aktiv tieneste som krigsreporter, bør ikke forstås som suicidalitet, men som en identifikasjon med landsmenn som var i forreste linje (Egeland 1953).

Ingen onsker en krig for at suicidrater skal reduseres. Men endringen under annen verdenskrig vitner om suicidalitet er et fenomen som i stor grad reguleres av samfunnet og ikke-medisinske faktorer. Dette er en viktig lærdom, også for vår tid.

\section{REFERANSER}

Boëthius, MP (1991): Heder och samvete - Sverige og andra värdskriget. Stockholm: Norstedts.

Douglas ID (1967). The social meanings of suicide. New Tersey: Princeton university press.
Durkheim E (1897/2013) Le Suicide - Étude de Sociologie. Paris: Quadrige. Norsk oversettelse : Selvmordet. Gyldendal 1978

Egeland K (1953). Nordahl Grieg. Oslo: Gyldendal.

Enquist PO (1968). Legionärerna. Stockholm: Norstedts.

Evensmo S (1947). Englandsfarere. Oslo: Gyldendal.

Freud S (1991). Civilization, Society and Religion. London: Penguin.

Freud S (1904). Zur Psychopathologie des Alltagslebens. (Über Vergessen, Versprechen, Vergreifen, Aberglaube und Irrtum). S. Karger: Berlin (Reprint: Outlook Verlagsgesellschaft, Bremen 2012)

Giertsen F. Dødsårsaksregisteret - en viktig datakilde for medisinsk forskning. Tidsskr Nor Lægeforen 2002; 122:2551-4.

Goeschel C (2009). Suicide in Nazi Germany. Oxford University Press.

Graver HP (2015). Den tyske okkupasionen 1940-1945 og den norske rettsstaten. Oslo: Pax.

Hadenius, S et al (1974). Sverige efter 1900 - en modern politisk historia. Stockholm: Aldus/Bonniers.

Halbwachs M Les Causes du Suicide 1930/2002. Paris: Presses Universitaires. Engelsk oversettelse: The Causes of Suicide. London: Routledge 1978.

Hammerlin Y \& Enerstvedt RT (1988). Selvmord i virksomhetsforståelsens perspektiv. Oslo: Falken Forlag.

Hoel S (1947). Møte ved milepelen. Oslo: Gyldendal.

Langfeldt G (1951). Lærebok i klinisk psykiatri. Oslo: Aschehoug.

Lavik NI (1994). Norsk psykiatri og nazismen. Tidsskr Nor Lægefor 144 1687-9o.

Moberg W (1969). Beretninger fra mitt liv. Oslo: Cappelen (svensk originalutgave 1968).

Norström T (2013). Samband mellan alkohol och siälvmord på befolkningsnivå: en översikt. Suicidologi (18) 3: $10-15$

NOU 1995: 24 (Norges offentlige utredninger): Alkoholpolitikk i endring? Oslo: Statens trykning

Smedby B \& Schidler G (2006) Health Classifications in the Nordic Countries Historic development in a national and international perspective. København: Nordic Medico Statistical Committee.

Statistisk sentralbyrå (1961). Dødeligheten og dens årsaker i Norge 1856-1955. Oslo: Aschehoug.

Statistiska Centralbyrån (1955). Befolkningsrörelsen översikt för åren 1941-1950. Stockholm.

Sæter E \& Sæter S (2007). XU-I hemmeleg teneste 1940-1945. Oslo: Det norske samlaget.

Thorvik A (2007). "The character of Norwegians which appear to make them less prone to suicide». Herbert Hendins Suicide and

Scandinavia, 40 år etter. Suicidologi (12) 2: 6-10.

Thorvik A (2008). Å stå på Freuds skuldre: Hovedlinjer i psykodynamisk forståelse av suicid. Suicidologi (13) 3: 5-9.

Ulateig E (2015). Freden. Vigmostad og Biørke

Ultee W, Luijkx R \& Tubergen Fv (2009). The Netherlands and World War II, Jews and Suicide. I: L Sher \& A Vilens: War and Suicide. New York: Nova Science Publishers.

\section{Levert: 20.12.15/Revidert: 11.04.16/Godkjent:18.04.16}

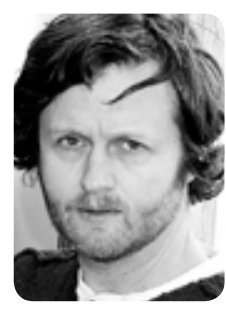

ARNE THORVIK er psykiater og avd.overlege ved Psykiatrisk fylkesavd. Sykehuset i Vestfold. Han disputerte for PhD-grad i 2011 med en avhandling bl.a. basert på dybdeintervjuer av pasienter med suicidproblematikk. Thorvik er medlem av redaksjonskomiteen ved Suicidologi. 


\title{
20-årsjubileum for NSSF
}

\author{
Det er i år 20 år siden Nasjonalt senter for selvmordsforskning \\ og -forebygging ble opprettet. 15. mars markerte de 20-årsjubileet \\ med seminar på Litteraturhuset i Oslo.
}

Da NSSF ble opprettet i 1996, var det for å skape og spre kunnskap om selvmordsforebygging i samfunnet.

Seminaret var en feiring av det senteret har oppnådd, men også en mobilisering til videre arbeid. I løpet av senterets driftstid har det skjedd en rivende utvikling på feltet, men det er fortsatt er en jobb å giøre.

\section{Må ikke bli selvtilfredse}

Det forebyggende arbeidet som giøres i Norge i dag er forbilledlig, men vi må passe på å ikke bli selvtilfredse. Det var beskjeden fra president i det internasjonale forbundet for selvmordsforebygging, professor Ella Arensman.

Hun startet sitt foredrag med å påpeke at NSSF har utviklet seg til et «center of excellence», innen forskning, men også i praksis giennom intervension og forebygging. Særlig fremhevet hun senterleder Lars Mehlums arbeid med barn og ungdom som verdensledende.

Samtidig pekte hun på at det fortsatt er store utfordringer. Statistikken i Norge går ned, men vi vi ligger fortsatt forholdsvis høyt, særlig for enkelte grupper.

Arensman poengterte også at selvmordsforebyggende arbeid er noe som aldri blir ferdig. Det vil stadig være mennesker som trenger hielp, og vi kan aldri sette oss ned og si oss fornøyd.

\section{Forebygging blant ungdom}

Lars Mehlum påpekte i sitt foredrag at selvmord er den vanligste dødsårsaken blant ungdom. Han kunne fortelle at for bare et tiår siden visste vi lite om effekten av forebyggingstiltakene. I dag vet vi mye mer, og vi vet at det er finnes tiltak som nytter.

Men også Mehlum påpekte at til tross for at vi har fått mye ny kunnskap de siste årene er det fortsatt et kunnskapsgap. Særlig er det et behov for å systematisere forebyggingen.

I tillegg til forskerne fikk både pasienter og pårørende rom i seminaret. Thea Røstbakken fortalte gripende om hvor viktig enkeltmenneskene hadde vært i hennes kamp for å komme seg giennom en vanskelig ungdomstid. Christoffer Vestli fortalte om arbeidet som giøres blant etterlatte, og om den betydningen det frivillige arbeidet har både i sorgarbeid og forebygging.

Av Guro Flinterud

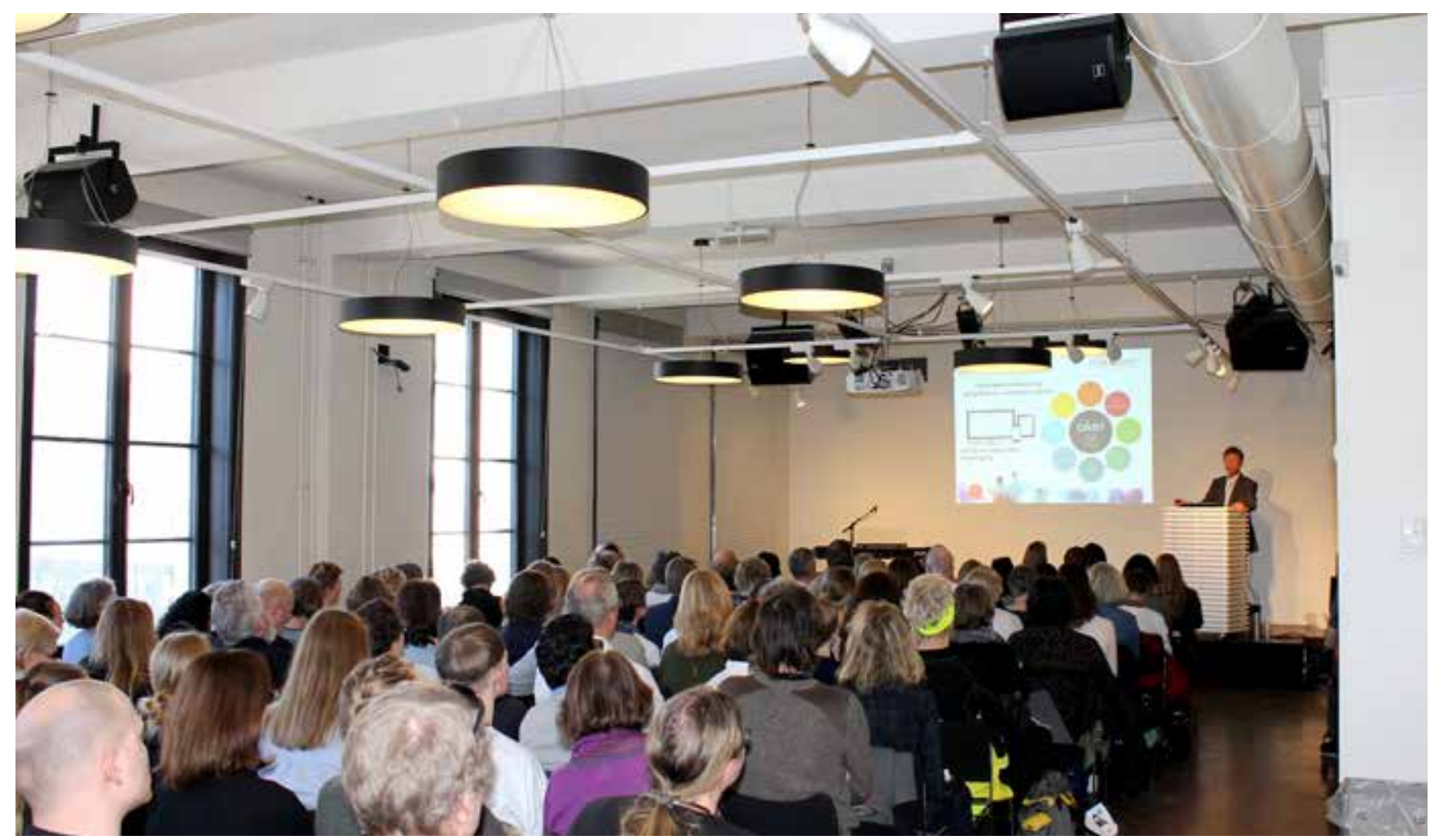

Salen var full da NSSF markerte sitt 20-årsjubileum med seminar om selvmordsforebygging. Foto: Hanne Holmesland/ UiO 